\title{
Influence of in ovo injection and subsequent provision of silver nanoparticles on growth performance, microbial profile, and immune status of broiler chickens
}

\author{
This article was published in the following Dove Press journal: \\ Open Access Animal Physiology \\ 21 September 2012 \\ Number of times this article has been viewed
}

\author{
Lane Pineda' \\ Ewa Sawosz $z^{2}$ \\ Charlotte Lauridsen ${ }^{3}$ \\ Ricarda M Engberg ${ }^{3}$ \\ Jan Elnif' \\ Anna Hotowy' \\ Filip Sawosz' \\ Andrè Chwalibog' \\ 'Department of Veterinary Clinical \\ and Animal Sciences, Copenhagen \\ University, Denmark; ${ }^{2}$ Department of \\ Animal Nutrition and Feed Science, \\ Warsaw University of Life Sciences, \\ Poland; ${ }^{3}$ Department of Animal \\ Science, Aarhus University, Denmark
}

Correspondence: Andrè Chwalibog University of Copenhagen, Department of Veterinary Clinical and Animal Sciences, Grønnegårdsvej 3,

I870 Frederiksberg C, Denmark

Tel +453533 3044

Fax +45 35333020

Email ac@life.ku.dk
Background: Because of their unique biological properties and strong antimicrobial activity, silver nanoparticles have received considerable attention and been used widely in an increasing number of consumer and medical products. In the present study, the potential of silver nanoparticles as an alternative antimicrobial growth-promoting supplement for broiler chickens was investigated.

Methods: On day 1 of incubation, two groups of fertile eggs were injected with colloidal silver nanoparticles $10 \mathrm{mg} / \mathrm{kg}$ or $20 \mathrm{mg} / \mathrm{kg}$. A third group was not injected and designated as a control group. At day 7 post-hatching, drinking water containing three silver nanoparticle concentrations $(0,10$, and $20 \mathrm{mg} / \mathrm{kg}$ ) was offered for 4 weeks. Body weight and feed consumption were measured weekly. At days 22 and 36, blood samples and intestinal contents were collected to evaluate the effects of the silver nanoparticles on plasma concentrations of immunoglobulins (IgG and $\operatorname{IgM}$ ) and intestinal microflora.

Results: In ovo injection of silver nanoparticles $10 \mathrm{mg} / \mathrm{kg}$ and $20 \mathrm{mg} / \mathrm{kg}$ and subsequent provision in the drinking water during the post-hatch period reduced feed intake by about $5.0 \mathrm{~g}$ /day $(P=0.02)$ and body weight by about $41.0 \mathrm{~g}(P=0.001)$; however, no concurrent effect on feed conversion ratio was observed. Bacterial populations in the ileum were not affected. Numbers of lactose-negative enterobacteria and lactic acid bacteria decreased in the cecum $(P<0.05)$. Silver nanoparticle supplementation increased the concentration of acetic acid $(P=0.006)$, but not the concentrations of butyric, propionic, valeric, and succinic acid in the cecum. No treatment effects on plasma concentrations of IgG and IgM were noted.

Conclusion: Silver nanoparticles affect feed intake, acetic acid concentration, numbers of lactosenegative and lactic acid bacteria, and immunoglobulin levels in broiler chickens. Silver nanoparticles are a potent antimicrobial agent for use in these birds. However, their activity and impact on growth performance should be explored further in a commercial poultry production setting.

Keywords: silver nanoparticles, feed additives, chicken, intestinal microflora, immunoglobulins

\section{Introduction}

The widespread application of antibiotics in animal production and human medicine has resulted in tremendous increases in animal food production and unprecedented advances in the protection of human health. ${ }^{1}$ However, the overuse and misuse of antibiotics required for human medical prophylaxis and therapeutics in animal food production has created a generation of antibiotic-resistant pathogens, and reduced the sensitivity to antibiotics. For example, the incorporation of antimicrobials into 
the standard management practices used in modern broiler chicken production systems has resulted in increased numbers of antibiotic-resistant bacteria, some of which are pathogenic to humans. ${ }^{2,3}$ In this respect, there is now a search underway to identify alternative health and growthpromoting additives to maintain gut health and efficient growth performance in poultry. ${ }^{4}$

Recently, renewed research interest has been directed towards use of silver as an alternative antimicrobial agent. ${ }^{5-7}$ Metallic silver compounds and their ions have long been known to have unique antibacterial properties. Silver has been used since time immemorial for the treatment of burns, wounds, and bacterial infections. ${ }^{6}$ However, the development of several low-cost antibiotics and the toxicity associated with ionic silver have markedly decreased its use as an antimicrobial agent. ${ }^{6,7}$

The advent of nanotechnology and its applications has enabled the chemical, physical, and optical properties of metals to be altered dramatically. ${ }^{6}$ This technology has made it possible to engineer silver in the nanosize range (1-100 nm) with a large functional surface area and more atoms exposed on the surface of the nanoparticles. At the nanoscale, silver is more reactive than larger particles, and it has been demonstrated that toxicity can be minimized or eliminated using "nano amounts" of the active substance. ${ }^{8}$ Furthermore, silver nanoparticles have unique biological properties and broad-spectrum biocidal activity against micro-organisms. ${ }^{9-13}$ In the past, numerous studies have documented the antimicrobial activity of silver nanoparticles in vitro. Silver nanoparticles have effective biocidal activity against a broad spectrum of Gramnegative bacteria, including Acinetobacter, Escherichia, Pseudomonas, Salmonella, and Vibrio, as well as Grampositive bacteria, such as Bacillus, Clostridium, Enterococcus, Listeria, Staphylococcus, and Streptococcus. ${ }^{14-19}$ Because of these unique biological properties and strong antimicrobial activity, silver nanoparticles have received considerable attention and are being used extensively in an increasing number of consumer and medicinal products. ${ }^{17,19}$

In poultry production, it is hypothesized that silver nanoparticles may affect intestinal microbial populations and improve the health and immunological status of the birds. This can provide the birds with an opportunity to expend less metabolic effort for immunological control purposes, and to use surplus nutrients for other physiological and productive purposes. ${ }^{4}$ Furthermore, it is speculated that, as a carrier of available oxygen, silver nanoparticles could also be a potent modifier of metabolism. Silver nanoparticles can be deposited at the tissue and cell level via in ovo injection, and it is possible that the oxygen that accumulates in the octahedral holes of silver nanoparticles may increase anabolic activity and subsequently stimulate growth and development. Moreover, the in ovo method of introducing silver nanoparticles could be a valuable technique for earlier establishment of immunity and intestinal integrity of the birds, which are essential to reach maximum potential for growth and feed efficiency. ${ }^{4}$

The use of silver nanoparticles in animal production has great potential. However, there are only a few investigations regarding the use of silver nanoparticles in animal nutrition. ${ }^{8,20-22}$ The objectives of this study were to investigate the effects of in ovo administration of silver nanoparticles in the pre-hatch period and subsequent provision of silver nanoparticles in the drinking water during the post-hatch period on the growth performance, microbial profile of the ileum and cecum, and immune status of broiler chickens.

\section{Materials and methods}

\section{Animals and management}

On day 1 of incubation, fertile eggs from a 37-week-old Ross $\times$ Ross 308 breeder flock were injected with a distilled water solution containing hydrocolloidal silver nanoparticles $10 \mathrm{mg} / \mathrm{kg}(\mathrm{n}=96)$ or $20 \mathrm{mg} / \mathrm{kg}(\mathrm{n}=96)$. Another group from the same batch of eggs was not injected and was designated the control group ( silver nanoparticles $0 \mathrm{mg} / \mathrm{kg} ; \mathrm{n}=96$ ). The injection procedure was performed according to the method described by Sawosz et al. ${ }^{22}$ Briefly, $0.3 \mathrm{~mL}$ of hydrocolloidal silver nanoparticle solution was injected in ovo into the albumen (two-thirds of egg height from the blunt end) using a sterile 27 gauge, $20 \mathrm{~mm}$ needle. Before and immediately after injection, the hole was sterilized with alcohol swabs and thereafter sealed with hypoallergenic tape. The eggs were then incubated in an incubator for 21 days under standard conditions $\left(37.8^{\circ} \mathrm{C}, 55 \%\right.$ humidity, turned once per hour during the first 18 days, and at $37^{\circ} \mathrm{C}$ and $60 \%$ humidity from day 19 till hatching). At hatching, the chicks were brooded in pens furnished with a heat lamp, at an ambient temperature of $27^{\circ} \mathrm{C}-33^{\circ} \mathrm{C}$ and a 23 -hour light to one-hour dark lighting program for 6 days post-hatching.

On day 7, 48 chicks from each group were randomly selected, weighed, leg-banded, and transferred to metabolic cages $(0.5 \times 0.5 \times 0.5 \mathrm{~m})$ equipped with a feeder and nipple drinker, with four birds per cage and 12 replications. The birds were fed ad libitum on a commercial broiler diet (Table 1) and had free access to drinking water containing one of the silver nanoparticle concentrations $(0,10$, and $20 \mathrm{mg} / \mathrm{kg})$ 
Table I Ingredients and nutrient composition of the diet

\begin{tabular}{|c|c|}
\hline & Percentage \\
\hline \multicolumn{2}{|l|}{ Ingredient } \\
\hline Wheat & 61.8 \\
\hline Soy bean meal & 16.3 \\
\hline Corn & 7.00 \\
\hline Oat & 5.40 \\
\hline Sunflower meal & 5.00 \\
\hline Vegetable fat & 1.00 \\
\hline Calcium carbonate & 1.50 \\
\hline Monocalcium phosphate & 1.00 \\
\hline L-lysine (VitaLys ${ }^{\circledR}$ Dry 53) ${ }^{\mathrm{a}}$ & 0.36 \\
\hline Agro Denmark 40 & 0.30 \\
\hline Rock salt & 0.20 \\
\hline Sodium bicarbonate & 0.17 \\
\hline DL-methionine & 0.15 \\
\hline Threonine (98\%) & 0.05 \\
\hline Phytase premix ${ }^{c}$ & 0.03 \\
\hline Enzyme $^{d}$ & 0.02 \\
\hline \multicolumn{2}{|l|}{ Analyzed values } \\
\hline Crude protein & 17.6 \\
\hline Crude fat & 3.3 \\
\hline Crude fiber & 3.8 \\
\hline Ash & 5.2 \\
\hline \multicolumn{2}{|l|}{ Feed table values } \\
\hline Metabolizable energy, MJ/kg & 12.20 \\
\hline Lysine, g/kg & 8.7 \\
\hline Methionine, $\mathrm{g} / \mathrm{kg}$ & 4.1 \\
\hline Cysteine, g/kg & 3.2 \\
\hline
\end{tabular}

Notes: ${ }^{2}$ italys ${ }^{\circledR}$ Dry 53 (Vitalys I/S, Esbjerg, Denmark) provides L-lysine sulfate produced by fermentation (Corynebacterium glutamicum) with a lysine content of $530 \mathrm{~g} / \mathrm{kg}$; 'supplied per $\mathrm{kg}$ diet: 500 units phytase; $10 \mathrm{mg}$ copper sulfate; $0.30 \mathrm{mg}$ selenium; $13.50 \mathrm{IU}$ (vitamin A); $75 \mathrm{mg}$ alfa-tocopherol (vitamin E); $50 \mathrm{mg}$ choline; 3.0 IU vitamin D3; '6-phytase (3.13.26 EU number 4al640) contains 1666.67 FTU per $g$ of premix; ${ }^{d}$ specific active enzymes: 3000 units endo I,4 betaglucanase; 7200 units endo I,4 betaxylanase.

for 4 weeks. The experiment was carried out in accordance with the requirements of the Danish Ministry of Justice regarding housing and treatment of experimental animals (Law 726, September 1993).

\section{Nanosolution}

The hydrocolloidal silver nanoparticles were obtained from Nano-Tech (Warsaw, Poland) and produced by a nonexplosive high voltage patented method (Polish Patent 3883399) from high purity metals (99.99\%) and demineralized water of high purity. The hydrocolloids contained a concentration of silver nanoparticles at $50 \mathrm{mg} / \mathrm{kg}$ and a particle size was in the range of $2-35 \mathrm{~nm}$, according to evaluation by transmission electron microscopy, as described elsewhere. ${ }^{23}$ The desired silver nanoparticle concentrations of $10 \mathrm{mg} / \mathrm{kg}$ and $20 \mathrm{mg} / \mathrm{kg}$ used in the study were prepared by diluting the original concentration of silver nanoparticle solution in distilled water.

\section{Plasma immunoglobulins and microbial analysis}

On days 22 and 36 of age, 72 chickens were killed by cervical dislocation. Blood was drawn from the heart immediately and afterwards collected in the heparinized tubes. After centrifugation at $2000 \mathrm{~g}$ for 10 minutes, blood plasma was obtained and stored at $-20^{\circ} \mathrm{C}$ until further analysis. Concentrations of immunoglobulins $\mathrm{G}$ and $\mathrm{M}$ were measured using commercial kits (Bethyl Laboratories Inc, Montgomery, TX). The contents of the ileum and cecum from 24 birds per treatment group were sampled and pooled according to intestinal segment at days 22 and 36 of age. The numbers of anerobic bacteria, lactic acid bacteria, lactose-negative enterobacteria, coliform bacteria, enterococci, and Clostridium perfringens were counted on appropriate nonselective and selective agar plates, as described previously. ${ }^{24}$ Intestinal $\mathrm{pH}$ and concentrations of short-chain fatty acids and lactic acid were analyzed, as described earlier. ${ }^{25}$

\section{Calculations}

Relative chick weight was calculated as hatching weight relative to egg weight at setting ([g of chick/g of egg at setting] $\times 100$ ). Body weight, feed consumption, and water intake were recorded each week, starting at day 7 till 36 days of age. The mean body weight gain was calculated from the initial and final weights of the birds. Feed intake was calculated from the difference between the amount of feed given and feed residues. The feed conversion ratio was calculated as the feed consumption to weight gain ratio.

\section{Statistical analysis}

The data were analyzed using the general linear model procedure of $\mathrm{SAS}^{26}$ considering the main effects of treatments (silver nanoparticles 0,10 , and $20 \mathrm{mg} / \mathrm{kg}$ ), age, and interactions between these variables. The Tukey-Kramer honestly significant difference test was used to test separation of the means at a significance level of $P<0.05$. The results are presented as the pooled mean and standard error for each variable.

\section{Results}

The silver nanoparticles had no effect on embryo development, and no significant differences in hatching parameters were observed (results not shown), ie, egg weight at setting $(60.8 \pm 1.83 \mathrm{~g})$, hatchability $(71.1 \pm 3.31 \%)$, hatching weight $(44.5 \pm 1.23 \mathrm{~g})$, and relative chick weight $(73.2 \pm 0.80 \%)$. 


\section{Growth performance}

In ovo injection of silver nanoparticles $10 \mathrm{mg} / \mathrm{kg}$ and $20 \mathrm{mg} / \mathrm{kg}$ and subsequent provision in the drinking water post-hatching reduced the feed intake by about $5.0 \mathrm{~g} /$ day $(P=0.02$; Table 2), and a consequent reduction in body weight was noted ( $P=0.001$; Table 2$)$; however, no concurrent effect on feed conversion ratio was observed. There was an interaction between the silver nanoparticle concentration and age for body weight of bird $(P<0.0001)$. The body weight of broilers supplemented with silver nanoparticles was $80-100 \mathrm{~g}$ lower at 29 and 36 days of age compared with the nonsupplemented control group. Age had a significant effect on all variables measured in relation to growth performance.

\section{Microbial profile and immune status}

The populations of Escherichia coli, lactose-negative enterobacteria, and $C$. perfringens were not affected by pre-hatch and post-hatch silver nanoparticle exposure $(P>0.05$; Table 3$)$. However, the counts of lactic acid bacteria tended to decrease when silver nanoparticles were added ( $P=0.02$; Table 3$)$. C. perfringens counts decreased from days 22 to 36 ( $P=0.001$; data not shown).

With the exception of lactic acid bacteria and lactosenegative enterobacteria, the populations of bacteria in the cecum were not affected by treatment with silver nanoparticles $(P>0.05$; Table 3$)$. The numbers of lactic acid bacteria and lactose-negative enterobacteria decreased following in ovo injection and subsequent provision of silver nanoparticles in the drinking water (both $P<0.05$; Table 3).

Several organic acids produced by micro-organisms in the ileum and cecum were measured, ie, acetic, formic, butyric, isobutyric, isovaleric, lactic, and succinic acid; however, due to the very low concentrations recorded, only acetic and lactic

Table 2 Growth performance of broiler chickens after pre-hatch and post-hatch treatment with silver nanoparticles ${ }^{\neq}$

\begin{tabular}{llll}
\hline $\begin{array}{l}\text { Silver nanoparticles } \\
(\mathbf{m g} / \mathbf{k g})\end{array}$ & $\begin{array}{l}\text { Body } \\
\text { weight, } \mathbf{g}\end{array}$ & $\begin{array}{l}\text { Feed } \\
\text { intake, } \mathbf{g}\end{array}$ & FCR \\
\hline 0 & $612^{\mathrm{b}}$ & $71.3^{\mathrm{a}}$ & 1.8 \\
$\mathrm{I0}$ & $562^{\mathrm{a}}$ & $67.1^{\mathrm{b}}$ & 1.9 \\
20 & $580^{\mathrm{a}}$ & $66.7^{\mathrm{b}}$ & 1.8 \\
$\mathrm{SE}$ & 4.76 & 0.02 & 0.02 \\
$\boldsymbol{P}$ values & & & \\
Silver nanoparticles & $0.00 \mathrm{I}$ & 0.02 & 0.13 \\
Age & $<0.000 \mathrm{I}$ & $<0.000 \mathrm{I}$ & $<0.000 \mathrm{I}$ \\
Silver nanoparticles $\times$ age & 0.01 & 0.38 & 0.85 \\
\hline
\end{tabular}

Notes: $\neq$ Values are pooled means of 12 cages, each containing four birds; ${ }^{a, b}$ within columns, means with different superscripts differ significantly $(P<0.05)$.

Abbreviations: FCR, feed conversion ratio; SE, pooled standard error. acid in the ileum and acetic, propionic, butyric, valeric, and succinic acid in the cecum were analyzed statistically.

The acetic and lactic acid concentrations in the ileum were not affected by supplementation with silver nanoparticles at either concentration $(P>0.05$; Table 4$)$. On the other hand, age had a significant effect on the concentration of acetic acid (5.8 versus $7 \mu \mathrm{mol} / \mathrm{g}$ ) and $\mathrm{pH}$ (7.1 versus 7.5$)$, and an interaction effect was found between silver nanoparticle concentration and age for the same parameters. At day 22, the concentration of acid and the $\mathrm{pH}$ value were lower for silver nanoparticles at $10 \mathrm{mg} / \mathrm{kg}$ compared with those at $0 \mathrm{mg} / \mathrm{kg}$ and $20 \mathrm{mg} / \mathrm{kg}$.

The silver nanoparticles increased the concentration of acetic acid $(P=0.02)$, but not the concentrations of butyric, propionic, valeric, and succinic acid in the cecum, (all $P>0.05$; Table 4). The $\mathrm{pH}$ of the ileal and cecal contents was not affected by treatment with silver nanoparticles ( $P>0.05$; Table 4$)$. The concentration of organic acids in the cecum were higher at day 36 than at day 22 (all $P<0.001$; data not shown).

There were no discernible effects of pre-hatch and posthatch silver nanoparticle exposure on plasma concentrations of $\operatorname{IgG}$ and $\operatorname{IgM}(P>0.05$; Table 5$)$. $\operatorname{IgG}$ and IgM levels were significantly higher at day 36 than at day $22(P<0.001$; data not shown), but no significant interaction effects between silver nanoparticle supplementation and age were noted $(P>0.05$; Figure 1).

\section{Discussion}

Because of their unique biological properties and strong antimicrobial activity, silver nanoparticles have received considerable attention and are being used widely in an increasing number of consumer and medicinal products. ${ }^{17,19}$ In the current study, we investigated the potential of silver nanoparticles as an alternative antimicrobial growthpromoting supplement for chickens, and it was hypothesized that silver nanoparticles may affect intestinal microbial populations and increase anabolic activity, thereby stimulating the development and growth of animals following in ovo administration of silver nanoparticles to hatching eggs in the pre-hatch period and subsequent provision in the drinking water during the post-hatch period.

\section{Growth performance}

The results indicate that in ovo injection of silver nanoparticles into the air sacs of embryos and subsequent provision in the drinking water post-hatch negatively affects the postnatal growth performance of broiler chickens. The body weight 
Table 3 Numbers of dominant bacterial groups in the contents of ileum and cecum (log colony-forming units/g) of broilers after treatment with increasing concentrations of silver nanoparticles ${ }^{*}$

\begin{tabular}{|c|c|c|c|c|c|c|c|}
\hline & \multicolumn{4}{|c|}{ Silver nanoparticles (mg/kg) } & \multicolumn{3}{|l|}{$P$ value } \\
\hline & 0 & 10 & 20 & SE & $\begin{array}{l}\text { Silver } \\
\text { nanoparticles }\end{array}$ & Age & $\begin{array}{l}\text { Silver } \\
\text { nanoparticles } \times \text { age }\end{array}$ \\
\hline \multicolumn{8}{|l|}{ Ileum } \\
\hline Anerobic bacteria & 8.2 & 7.8 & 8.0 & 0.11 & 0.32 & 0.32 & 0.78 \\
\hline Lactic acid bacteria & 8.8 & 8.2 & 8.2 & 0.11 & 0.07 & 0.26 & 0.87 \\
\hline Lactose-negative bacteria & 4.5 & 4.5 & 4.5 & 0.09 & 0.95 & 0.54 & 0.07 \\
\hline Coliform bacteria & 5.7 & 5.3 & 5.1 & 0.15 & 0.37 & 0.94 & 0.83 \\
\hline Enterococci & 5.7 & 6.3 & 6.2 & 0.18 & 0.42 & 0.96 & 0.64 \\
\hline Clostridium perfringens & 4.8 & 4.5 & 4.6 & 0.21 & 0.91 & 0.001 & 0.95 \\
\hline \multicolumn{8}{|l|}{ Cecum } \\
\hline Anerobic bacteria & 8.9 & 8.8 & 8.8 & 0.06 & 0.65 & 0.49 & 0.98 \\
\hline Lactic acid bacteria & $9.1^{\mathrm{a}}$ & $8.9^{a, b}$ & $8.6^{\mathrm{b}}$ & 0.07 & 0.02 & 0.30 & 0.99 \\
\hline Lactose-negative bacteria & $5.9^{\mathrm{a}}$ & $5.3^{b}$ & $5.6^{\mathrm{a}, \mathrm{b}}$ & 0.10 & 0.04 & 0.91 & 0.47 \\
\hline Coliform bacteria & 7.6 & 7.6 & 7.6 & 0.06 & 1.00 & 0.84 & 0.88 \\
\hline Enterococci & 6.9 & 7.1 & 6.9 & 0.13 & 0.70 & 0.82 & 0.71 \\
\hline Clostridium perfringens & 4.7 & 4.7 & 5.3 & 0.23 & 0.48 & 0.95 & 0.88 \\
\hline
\end{tabular}

Notes: ${ }^{\vee}$ Values are pooled means of six cages, each containing four birds; ${ }^{a, b}$ within rows, means with different superscripts differ significantly $(P<0.05)$.

Abbreviation: SE, pooled standard error.

was lower in the silver nanoparticle-supplemented broilers compared with the control group, which is not consistent with the results of other studies ${ }^{21,22}$ demonstrating that silver nanoparticles neither promote nor depress growth in pigs and chickens kept under optimal conditions.

The lower growth rate of broilers treated with silver nanoparticles in the present investigation could be due to the lower feed intake of the birds, which was reduced by about $5 \mathrm{~g} /$ day. The reason behind the effect of the silver nanoparticles on feed intake is not known and was not extensively investigated in the present study. However, it can be speculated that the decrease in feed intake may be a response to the process of mechanical injection rather than silver nanoparticle exposure, because although conflicting results were obtained in quail ${ }^{8}$ and weaned pigs, ${ }^{21}$ no negative effect on feed intake has been reported as a result of silver nanoparticle supplementation in the feed or via the drinking water. The feed conversion ratio for the broilers did not differ between the treatment groups, which is accordance with the findings in quail ${ }^{8}$ and broiler chickens ${ }^{27}$ provided with silver nanoparticles via the drinking water, but not with data from weanling pigs supplemented with silver nanoparticle powder in the diet. ${ }^{7}$ These conflicting results suggest that poultry species are either less sensitive to silver nanoparticle treatment than pigs, or that silver nanoparticles in powdered form provided via the feed is

Table $4 \mathrm{pH}$ and short-chain fatty acid concentrations $(\mu \mathrm{mol} / \mathrm{g})$ of ileal and cecal contents of broilers after pre-hatch and post-hatch treatment with silver nanoparticles ${ }^{\neq}$

\begin{tabular}{|c|c|c|c|c|c|c|c|}
\hline & \multicolumn{4}{|c|}{ Silver nanoparticles (mg/kg) } & \multicolumn{3}{|l|}{$P$ value } \\
\hline & 0 & 10 & 20 & SE & $\begin{array}{l}\text { Silver } \\
\text { nanoparticles }\end{array}$ & Age & $\begin{array}{l}\text { Silver } \\
\text { nanoparticles } \times \text { age }\end{array}$ \\
\hline \multicolumn{8}{|l|}{ Ileum } \\
\hline Acetic acid & 6.5 & 6.2 & 6.4 & 0.20 & 0.73 & 0.005 & 0.01 \\
\hline Lactic acid & 16.0 & 15.6 & 11.9 & 2.09 & 0.67 & 0.14 & 0.68 \\
\hline $\mathrm{pH}$ & 7.2 & 7.3 & 7.4 & 0.05 & 0.51 & 0.002 & 0.04 \\
\hline \multicolumn{8}{|l|}{ Cecum } \\
\hline Acetic acid & $63.8^{b}$ & $72.4^{\mathrm{a}}$ & $75.8^{\mathrm{a}}$ & 1.72 & 0.02 & 0.0001 & 0.76 \\
\hline Propionic acid & 4.0 & 4.9 & 4.6 & 0.16 & 0.76 & 0.001 & 0.58 \\
\hline Butyric acid & 17.5 & 18.6 & 17.0 & 0.96 & 0.06 & 0.000 & 0.21 \\
\hline Valeric acid & 0.8 & 1.0 & 0.9 & 0.05 & 0.35 & 0.004 & 0.91 \\
\hline Succinic acid & 9.8 & 13.9 & 9.4 & 1.43 & 0.47 & $<0.0001$ & 0.57 \\
\hline $\mathrm{pH}$ & 6.0 & 5.9 & 5.9 & 0.06 & 0.69 & 0.48 & 0.92 \\
\hline
\end{tabular}

Notes: ${ }^{\vee}$ Values are pooled means of six cages, each containing four birds; a,b within rows, means with different superscripts differ significantly $(P<0.05)$. Abbreviation: SE, pooled standard error. 
Table 5 Concentration of immunoglobulins $M$ and $G$ in broiler plasma after pre-hatch and post-hatch treatment with silver nanoparticles ${ }^{ \pm}$

\begin{tabular}{lll}
\hline Silver nanoparticles $(\mathbf{m g} / \mathbf{k g})$ & lgM & IgG \\
\hline 0 & 0.14 & 0.69 \\
10 & 0.11 & 0.57 \\
20 & 0.14 & 0.62 \\
SE & 0.01 & 0.03 \\
$P$ value & & \\
Silver nanoparticles & 0.40 & 0.78 \\
Age & $<0.000$ I & $<0.000$ I \\
Silver nanoparticles $\times$ age & 0.69 & 0.82 \\
\hline
\end{tabular}

Note: $₹$ Values are pooled means of 12 cages, each containing four birds. Abbreviations: Ig, immunoglobulin; SE, pooled standard error.

more stable than in the colloidal form administered via the drinking water. ${ }^{8}$

\section{Microbial profile and immune status}

Several studies have established the in vitro bactericidal activity of silver nanoparticles against Gram-positive and Gram-negative bacteria including antibiotic-resistant strains. Silver nanoparticles, even in low concentrations, exert toxic properties on Acinetobacter, Escherichia, Pseudomonas, Salmonella, Vibri, Bacillus, Clostridium, Enterococcus, Listeria, Staphylococcus, Streptococcus, methicillin-resistant and vancomycin-resistant Staphylococcus aureus, and Enterococcus faecium. ${ }^{14-19,28-32}$ In our study, the antimicrobial activity of silver nanoparticles against Gram-positive and Gram-negative bacteria was confirmed under in vivo conditions. However, this activity seems to be limited to certain species of bacteria. Silver nanoparticle supplementation reduced the counts of lactic acid bacteria and lactose-negative enterobacteria, but did not affect cecal numbers of anerobic, coliform bacteria, enterococci, and $C$. perfringens. The present

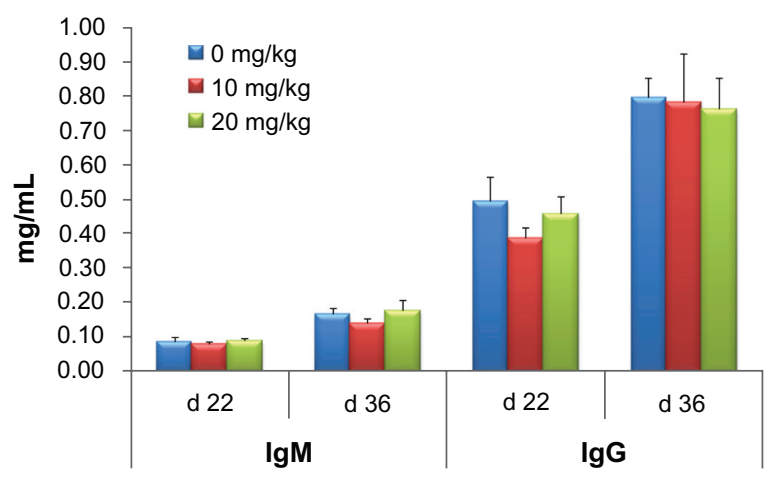

Figure I Interaction effect between age (d 22 and 36 ) and pre and post-hatch $\mathrm{AgNano}$ treatment on the concentration of lgM and IgG in plasma of broiler chickens.

Note: Values are means and standard errors of 12 cages, each containing 4 birds at $d 22$ and 36. data demonstrate that although silver nanoparticles have a very significant antimicrobial effect in vitro, ${ }^{9-13,33-35}$ their activity under in vivo conditions seems to be limited to certain species of bacteria, ie, lactic acid bacteria and lactosenegative enterobacteria. The reason for this is unknown, but it could be that the diverse species and numbers of microorganisms in live chickens contributed to the different responses of bacteria to silver nanoparticles under in vivo and in vitro conditions. Furthermore, it has to be borne in mind that the microbiological status of the intestines was determined in birds kept under optimum experimental conditions and in a good state of health. It could be expected that silver nanoparticles would exhibit their greatest antimicrobial activity when birds are exposed to stressful conditions, eg, when levels of pathogenic bacteria are high. These results are in agreement with the findings of Sawosz et $\mathrm{al}^{8}$ who reported no significant reduction in the number of colonies of bacteria kept under strict hygienic and biosecurity conditions.

Lactic acid bacteria numbers in the present study are contrary to the data reported by Sawosz et al, ${ }^{8}$ who found a significant increase in the population of lactic acid bacteria in the ceca of quails supplied with water containing silver nanoparticles $25 \mathrm{mg} / \mathrm{kg}$. The reasons for these variations may reflect differences in the concentrations of silver nanoparticles, animal species, and dietary ingredients used in the study.

The mechanism of action of silver nanoparticles was not clear in the current study, but their activity against lactosenegative enterobacteria indicates that they could contribute to the control of Salmonella in poultry production. On the other hand, the decrease in the numbers of lactic acid bacteria might not be favorable for development of health-promoting probiotic or bacteriocin-like substances, which can be used for the prevention or treatment of bacterial infections. ${ }^{35,36}$ However, it was noted in the present study that the numbers of Enterococcus, a major genus of lactic acid bacteria, did not follow a continuing decline with the decrease in lactic acid bacteria, indicating that the decrease was not great enough to affect the population of these beneficial micro-organisms.

Overall, the changes in microbial composition are marginal. Given that no specific identification and quantification procedures other than culture count are followed, the changes observed might be just casual or represent spontaneous variability. This cannot be discounted in the present data. Our findings suggest that more studies need to be conducted in the commercial poultry production 
setting to provide further evidence regarding the antimicrobial activity of silver nanoparticles.

In recent years, the use of short-chain organic acids or short-chain fatty acids has been considered as a replacement for antibiotics. Short-chain fatty acids have specific antimicrobial activity and have long been utilized as food additives and preservatives. ${ }^{37,38}$ In the current study, the concentration of acetic acid was increased by silver nanoparticle supplementation independently of the lactic acid bacteria population. This result is puzzling because it is known that short-chain fatty acids are the end products of bacterial metabolism under anerobic conditions and the mechanism underlying the increase remains to be elucidated in future works. However, the increase in short-chain fatty acids indicates an increase in antibacterial activity, which is mediated by a subsequent decrease in $\mathrm{pH}$ inhibiting the growth of some bacteria. It has been reported that reduction in numbers of Enterobacteraceae, including Salmonella and Campylobacter, is associated with an increase in short-chain fatty acid levels (acetic, propionic, and butyric acid). ${ }^{39-42}$ Notably, in the present study, $\mathrm{pH}$ levels in the cecum were not correlated with an increase in short-chain fatty acid levels, suggesting that the antibacterial action of silver nanoparticles was not determined by change in $\mathrm{pH}$. Our results in general suggest that silver nanoparticles could increase acetic acid production, which may be of benefit in feed and animal production, ie, controlling mold and reducing bacterial growth in feed, and can also inhibit growth of micro-organisms in the gastrointestinal tract and improve feed utilization.

The concentrations of $\operatorname{IgG}$ and $\operatorname{IgM}$ in the plasma of broilers are not consistent with data from other researchers in which silver nanoparticles were only administered during the post-hatching period, ${ }^{27}$ and it was demonstrated that silver nanoparticles reduced plasma IgG concentrations in broilers at a later age. Interestingly, this effect on IgG was eliminated when the broilers were injected with silver nanoparticles at the embryonic stage, suggesting that silver nanoparticles do not interact with the humoral immune system when introduced via in ovo injection. The lack of effect on plasma immunoglobulin levels is interesting; however, the different results seen between the studies are difficult to explain, and further investigation is needed.

\section{Conclusion}

Our results indicate that the in vivo antimicrobial activity of silver nanoparticles in broiler chickens is limited to some species of bacteria and does not influence immunoglobulin levels. The feed intake and consequent body weight were reduced, but not the feed conversion ratio. Although our study did not show significant beneficial effects in broiler performance, further investigation in the commercial poultry production setting could lead to the development of feeding strategies for chickens to reduce the use of antibiotics as growth promoters.

\section{Acknowledgment}

This work was supported by a Danish Agency for Science Technology and Innovation grant (2106-08-0025).

\section{Disclosure}

The authors declare that they have no competing interests in this work.

\section{References}

1. Hume ME. Historic perspective: Prebiotics, probiotics, and other alternatives to antibiotics. Poult Sci. 2011;90:2663-2669.

2. Butaye P, Devriese LA, Haesebrouck F. Antimicrobial growth promoters used in animal feed: effects of less well known antibiotics on Gram-positive bacteria. Clin Microbiol Rev. 2003;16:175-188.

3. Diarra MS, Silversides FG, Diarrassouba F, et al. Impact of feed supplementation with antimicrobial agents on growth performance of broiler chickens, Clostridium perfringens and enterococcus counts, and antibiotic resistance phenotypes and distribution of antimicrobial resistance determinants in Escherichia coli isolates. Appl Environ Microbiol. 2007;73:6566-6576.

4. Ferket P. Strategies for finding alternatives to growth promoters, 2011. Available from: http://en.engormix.com/MA-poultry-industry/ management/articles/strategies-finding-alternatives-growth-t1771/ 124-p0.htm. Accessed August 1, 2012.

5. Monteiro DR, Gorup LF, TakamiyaAS, Ruvollo-FilhoAC, de Camargo ER, Barbosa DB. The growing importance of materials that prevent microbial adhesion:antimicrobial effect of medical devices containing silver. Int J Antimicrobial Agents. 2009;34:103-110.

6. Rai M, Yadav A, Gade A. Silver nanoparticles as a new generation of antimicrobials. Biotechnol Adv. 2009;27:76-83.

7. Fondevila M. Potential use of silver nanoparticles as an additive in animal feeding, 2010. Available from: http://www.intechopen.com/ articles/show/title/potential-use-of-silver-nanoparticles-as-an-additivein-animal-feeding. Accessed August 1, 2012.

8. Sawosz E, Binek M, Grodzik M, et al. Influence of hydrocolloidal silver nanoparticles on gastrointestinal microflora and morphology of enterocytes of quails. Arch Anim Nutr. 2007;61:444-451.

9. Lok CN, Ho CM, Chen R, et al. Proteomic analysis of the mode of antibacterial action of silver nanoparticles. J Proteome Res. 2006;5: 916-924.

10. Shrivastava S, Bera T, Roy A, Singh G, Ramachandrarao P, Dash D. Characterization of enhanced antibacterial effects of novel silver nanoparticles. Nanotechnology. 2007;18:225103.

11. Ahamed M, Posgai R, Gorey TJ, Nielsen M, Hussain SM, Rowe JJ. Silver nanoparticles induced heat shock protein 70 , oxidative stress and apoptosis in Drosophila melanogaster. Toxicol Appl Pharmacol. 2010; 242:263-269.

12. Lara H, Ayala-Núñez N, Ixtepan Turrent L, Rodríguez Padilla C. Bactericidal effect of silver nanoparticles against multidrug-resistant bacteria. World J Microbiol Biotechnol. 2010;26:615-621.

13. Sawosz E, Chwalibog A, Mitura K, et al. Visualisation of morphological interaction of diamond and silver nanoparticles with Salmonella enteritidis and Listeria monocytogenes. J Nanosci Nanotechnol. 2011;11: 7635-7641. 
14. Burrell RE, Heggers JP, Davis GJ, Wright JB. Efficacy of silver-coated dressings as bacterial barriers in a rodent burn sepsis model. Wounds. 1999;11:64-71.

15. Yin HQ, Langford R, Burrell RE. Comparative evaluation of the antimicrobial activity of Acticoat antimicrobial barrier dressing. J Burn Care Rehabil. 1999;20:195-200.

16. Morones JR, Elechiguerra JL, Camacho A, et al. The bactericidal effect of silver nanoparticles. Nanotechnology. 2005;16:2346-2353.

17. Kim JS, Kuk E, Yu KN, et al. Antimicrobial effects of silver nanoparticles. Nanomedicine. 2007;3:95-101.

18. Wijnhoven SWP, Peijnenburg WJGM, et al. Nanosilver - a review of available data and knowledge gaps in human and environmental risk assessment. Nanotoxicology. 2009;3:109-138.

19. Varner KE, El-Badawy A, Feldhake D, Venkatapathy R. State-Of-TheScience Review: Everything Nano Silver and More. Washington, DC: US Environmental Protection Agency; 2010.

20. Grodzik M, Sawosz E. The influence of silver nanoparticles on chicken embryo development and bursa of Fabricius morphology. J Anim Feed Sci. 2006;1:111-114.

21. Fondevila M, Herrer R, Casallas MC, Abecia L, Ducha JJ. Silver nanoparticles as potential antimicrobial additive for weaned pigs. Anim Feed Sci and Tech. 2009;150:259-269.

22. SawoszE, Grodzik M,Zielinska M, Niemiec T, Olszanska B, ChwalibogA. Nanoparticles of silver do not affect growth, development and DNA oxidative damage in chicken embryos. Eur Poult Sci. 2009;73: 208-213.

23. Chwalibog A, Sawosz E, Hotowy A, et al. Visualization of interaction between inorganic nanoparticles and bacteria or fungi. Int $J$ Nanomedicine. 2010;5:1085-1094.

24. Engberg RM, Hedemann MS, Leser TD, Jensen BB. Effect of zinc bacitracin and salinomycin on intestinal microflora and performance of broilers. Poult Sci. 2000;79:1311-1319.

25. Canibe N, Højberg O, Badsberg JH, Jensen BB. Effect of feeding fermented feed and fermented grain on gastrointestinal ecology and growth performance in piglets. J Anim Sci. 2007;85:2959-2971.

26. SAS Institute Inc. SAS Procedure Guide. Version 9.2. Cary, NC: SAS Institute Inc; 2009.

27. Pineda L, Chwalibog A, Sawosz E, et al. Effect of silver nanoparticles on growth performance, metabolism and microbial profile of broiler chickens. Arch Anim Nutr. 2012. DOI: 10.1080/1745039X.2012.710081.

28. Panáček A, Kvítek L, Prucek R, et al. Silver colloid nanoparticles: synthesis, characterization, and their antibacterial activity. JPhys Chem B. 2006;110:16248-16253.
29. Lee KJ, Nallathamby PD, Browning LM, Osgood CJ, Xu XH. In vivo imaging of transport and biocompatibility of single silver nanoparticles in early development of zebrafish embryos. ACS Nano. 2007;1:133-143.

30. Lok CN, Ho C, Chen R, HE Q, Yu W. Silver nanoparticles: partial oxidation and antibacterial activities. J Biol Inorg Chem. 2007;12: 527-534.

31. Shahverdi AR, Fakhimi A, Shahverdi HR, Minaian S. Synthesis and effect of silver nanoparticles on the antibacterial activity of different antibiotics against Staphylococcus aureus and Escherichia coli. Nanomedicine. 2007;3:168-171.

32. Yoon K-Y, Hoon Byeon J, Park J-H, Hwang J. Susceptibility constants of Escherichia coli and Bacillus subtilis to silver and copper nanoparticles. Sci Total Environ. 2007;373:572-575.

33. Cho KH, Park JE, Osaka T, Park SG. The study of antimicrobial activity and preservative effects of nanosilver ingredient. Electrochim Acta. 2005;51:956-960.

34. Pal S, Tak YK, Song JM. Does the antibacterial activity of silver nanoparticles depend on the shape of the nanoparticle? A study of the Gram-negative bacterium Escherichia coli. Appl Environ Microbiol. 2007;73:1712-1720.

35. Strompfová $\mathrm{V}$, Lauková A. In vitro study on bacteriocin production of Enterococci associated with chickens. Anaerobe. 2007;13:228-237.

36. Lahtinen S, Ouwehand AC, Salminen S, Wright AV. Lactic Acid Bacteria: Microbiological and Functional Aspects. 4th ed. Boca Raton, FL: CRC Press; 2012.

37. Diebner JJ, Buttin P. Use of organic acids as a model to study the impact of gut microflora on nutrition and metabolism. J Appl Poult Res. 2002;11:453-463.

38. Ricke SC. Perspectives on the use of organic acids and short chain fatty acids as antimicrobials. Poult Sci. 2003;82:632-639.

39. Van Der Wielen PW, Biesterveld JJ, Notermans S, et al. Role of volatile fatty acids in development of the cecal microflora in broiler chickens during growth. Appl Environ Microbiol. 2000;66:2536-2540.

40. Byrd J, Hargis B, Caldwell D, et al. Effect of lactic acid administration in the drinking water during preslaughter feed withdrawal on Salmonella and Campylobacter contamination of broilers. Poult Sci. 2001;80: 278-283.

41. Griggs JP, Jacob JP. Alternatives to antibiotics for organic poultry production. J Appl Poult Res. 2005;14:750-756.

42. Van Immerseel FJB, Russell FJ, Flythe MD, et al. The use of organic acids to combat Salmonella in poultry: a mechanistic explanation of the efficacy. Avian Pathol. 2006;35:182-188.
Open Access Animal Physiology

\section{Publish your work in this journal}

Open Access Animal Physiology is an international, peer-reviewed, open access journal publishing original research, reports, reviews and commentaries on all areas of animal physiology. The manuscript management system is completely online and includes a very

\section{Dovepress}

quick and fair peer-review system. Visit http://www.dovepress.com/ testimonials.php to read real quotes from published authors. 